\title{
Anterior segment optical coherence tomography of silicone oil keratopathy
}

\author{
Ahmad M Mansour ${ }^{1,2}$
}

${ }^{1}$ Department of

Ophthalmology, American University of Beirut, Beirut, Lebanon

${ }^{2}$ Department of

Ophthalmology, Rafic Hariri University Hospital, Lebanon

\section{Correspondence to}

Dr Ahmad M Mansour, ammansourmd@gmail.com

Accepted 12 August 2016
CrossMark

To cite: Mansour AM. BMJ Case Rep Published online: [please include Day Month Year] doi:10.1136/bcr-2016217023

\section{DESCRIPTION}

A 77-year-old woman underwent pars plana vitrectomy for recurrent retinal detachment with silicone oil injection 10 years before presentation. Also the patient was placed on antiglaucoma medications. The patient had a history of recurrent corneal ulcerations in both eyes due to severe dry eyes. Examination revealed no light perception with a disfiguring central opaque corneal bulge in the left eye (figure 1). Anterior segment optical coherence tomography (OCT) revealed a marked thickening of the stroma with diffuse round empty spaces between stromal fibres corresponding to intrastromal silicone oil droplets (figure 2). No treatment was offered because of poor prognosis.

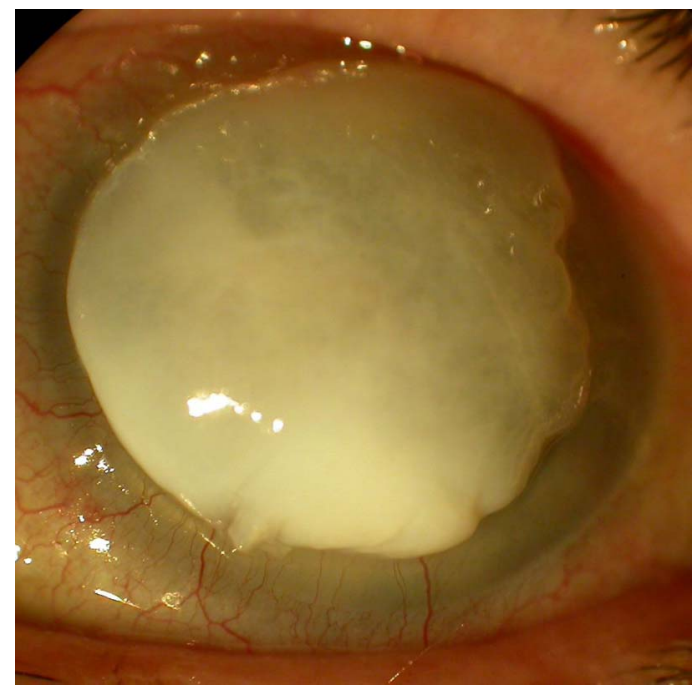

Figure 1 Anterior segment photograph of the left eye showing a white bulge occupying most of the cornea.
Silicone oil is used frequently as adjunct to modern vitreoretinal surgery because of transparency, minimal retinal toxicity and good intraocular tamponade. Complications include cataract formation, glaucoma and oil keratopathy. Silicone oil keratopathy manifests as corneal oedema, bullous keratopathy and rarely white cornea. The corneal endothelial damage stems from glaucoma and silicone oil touch of the endothelium. When the endothelium fails, silicone oil can penetrate into the stroma. Few histopathogical studies have been reported in eyes undergoing penetrating keratoplasty for severe silicone oil keratopathy. ${ }^{1-3}$ Ardjomand et $a l^{1}$ demonstrated in one corneal button that silicone oil traverses the cornea through defects in the Descemet membrane. Sekundo $e t a l^{2}$ noted the presence of a posterior collagenous layer above a severely attenuated endothelium in eight corneal buttons. OCT allows in vivo examination of the stroma and showed diffuse silicone oil droplets in between stromal fibres. This whitish colour of the cornea is similar to the colour of emulsified silicone oil.

\section{Learning points}

- Silicone oil can penetrate the corneal stroma through defects in the Descemet membrane or when the endothelium is severely damaged.

- Optical coherence tomography like histopathological sections show intrastromal silicone oil droplets.

- The white colour in silicone oil keratopathy stems from the white colour of the emulsified oil.

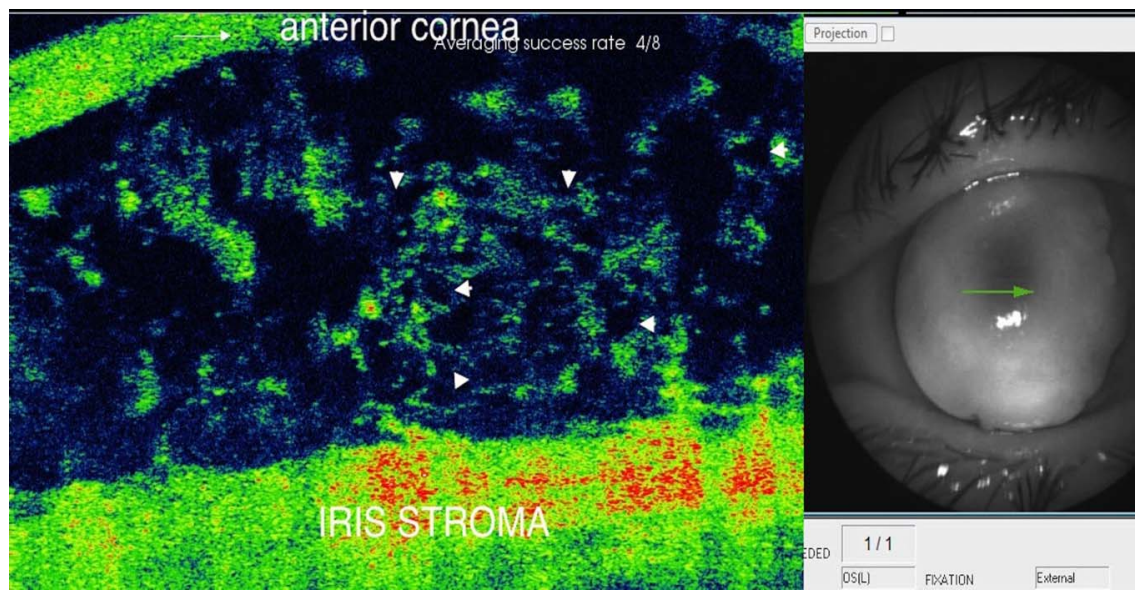

Figure 2 Anterior segment optical coherence tomography central horizontal scan showing diffusely scattered intrastromal silicone oil droplets throughout the stroma (arrowheads). 
Competing interests None declared.

\section{Patient consent Obtained.}

Provenance and peer review Not commissioned; externally peer reviewed.

\section{REFERENCES}

1 Ardjomand N, Haller-Schober EM, Faulborn J. Intracorneal silicone oil deposits. Ophthalmologe 2002;99:46-8.
2 Sekundo W, Hesse L, Schmidt J, et al. Histopathology of 8 corneal buttons after penetrating keratoplasty in silicone oil-associated keratopathy. Klin Monb/ Augenheilkd 2001;218:424-8.

3 Biswas J, Verma A, Davda MD, et al. Intraocular tissue migration of silicone oil after silicone oil tamponade: A histopathological study of enucleated silicone oil-filled eyes. Indian J Ophthalmol 2008;56:425-8.

Copyright 2016 BMJ Publishing Group. All rights reserved. For permission to reuse any of this content visit http://group.bmj.com/group/rights-licensing/permissions.

BMJ Case Report Fellows may re-use this article for personal use and teaching without any further permission.

Become a Fellow of BMJ Case Reports today and you can:

- Submit as many cases as you like

- Enjoy fast sympathetic peer review and rapid publication of accepted articles

- Access all the published articles

- Re-use any of the published material for personal use and teaching without further permission

For information on Institutional Fellowships contact consortiasales@bmjgroup.com

Visit casereports.bmj.com for more articles like this and to become a Fellow 